\title{
Intake and performance of confined crossbred heifers fed different lipid sources ${ }^{1}$
}

\author{
Giovani Fiorentini², Márcia Cristina Araújo Santana ${ }^{2}$, Alexandre Amstalden Moraes \\ Sampaio $^{2,3}$, Ricardo Andrade Reis ${ }^{2,3}$, Andressa Ferreira Ribeiro², Telma Teresinha \\ Berchielli 2,3
}

\footnotetext{
1 Project financed by Fundação de Amparo à Pesquisa do Estado de São Paulo (FAPESP).

2 Departamento de Zootecnia, Universidade Estadual de São Paulo (UNESP)/Campus Jaboticabal, São Paulo, Brasil.

${ }^{3}$ Pesquisador do CNPq/Membro do INCT-CA.
}

\begin{abstract}
The objective of this study was to evaluate the effect of different lipid sources on nutrient intake, performance, development and carcass characteristics of heifers raised in confinement. Twenty-one crossbreed heifers (Nellore $\times$ Santa Gertrudis $\times$ Braunvieh) received $600 \mathrm{~g} / \mathrm{kg}$ forage composed of corn silage and $400 \mathrm{~g} / \mathrm{kg}$ concentrate with a $58.0 \mathrm{~g} / \mathrm{kg}$ fat content in the total diet. The following lipid sources were used: soybeans, protected fat (Megalac- $\mathrm{E}^{\circledR}$ ) and soybean oil. The experimental design was completely randomized, with three treatments and seven replicates, and the means were compared by the Tukey test at 5\%. The protected fat diet resulted in a greater intake of dry matter $(8.80 \mathrm{~kg} / \mathrm{d})$ when compared with the other diets. The animals that were fed the protected fat diet had a higher average daily weight gain and slaughter weight. Feed conversion and protein efficiency rate were not influenced by lipid sources. Carcass yield was not influenced by the different diets.
\end{abstract}

Key Words: carcass, females, ingestion, protected fat, soy oil and soybean

\section{Introduction}

During dry seasons, feed shortage is a constant problem regardless of the production system, such as grazing or confinement, utilized to maintain animals. Thus, the use of diets that adequately supply protein and energy needs during this period is frequently studied. Increasing the energy density of the diet by adding lipid sources is a nutritional strategy that is used in the fattening of high genetic pattern cattle with the promotion of satisfactory performance results (Nelson et al., 2004). Numerous lipid sources may be used. However, few studies have demonstrated or identified the dietary effects that lipid sources have on the efficiency and consequent cattle performance. Various lipid sources, such as soybean oil and whole seeds from oilseed crops, are regularly used.

The main problem of using lipids rich in unsaturated fatty acids (UFAs) in diets for ruminants is their effect on intake and, consequently, on productivity performance (Allen, 2000). Although the energy concentration in lipids is greater than in carbohydrates and proteins, high levels of fat intake may reduce intake and amount of energy (NRC, 2001). Allen (2000) suggests that metabolic factors are related to reduction in intake, whereas the ruminal digestibility of the fibrous fraction is acutely affected by the use of unsaturated lipids in diets consisting of up to $50 \%$ forage (Bateman \& Jenkins, 1998).

Diets rich in grains cause a $\mathrm{pH}$ decrease in the rumen, which inhibits lipolysis and biohydrogenation (Demeyer \& Doreau, 1999). Thus, "protection” is an alternative to the use of lipid sources that principally benefit UFAs absorbed and deposited in muscle tissue. Calcium salts of fatty acids are commonly known as "protected fats". However, they are neither protected fats nor do they bypass digestion because they mix with the rumen contents, and their fatty acids are biohydrogenated. Although a small amount of calcium salts are dissociated in the rumen, no increase in the concentration of fatty acids esterified in a sufficient level affect the microbial metabolism. The lipid supplement in the form of protected fat has been recommended for ruminants because it is considered an inert ruminal fat source (Harvatine \& Allen, 2006). However, scientific studies that evaluate the effects of this practice on beef cattle performance as weight gain and milk production are limited.

Thus, this study was designed to evaluate the effect of different fat sources on nutrient intake and average 
daily weight gain of heifers raised in confinement and the effect of these sources on the carcass yield and carcass development from these heifers.

\section{Material and Methods}

The study was conducted at the Agrarian and Veterinary Sciences College - UNESP, Jaboticabal Campus, SP in an area belonging to the Animal Science Department. There were 24 partially covered individual stalls with cement floors, and each stall had water available and a single trough for roughage and concentrate.

In this study, 21 crossbred heifers (Nellore $\times$ Santa Gertrudis $\times$ Braunvieh) of approximately 14 months of age were used. The animals were derived from an experiment that evaluated the sward structure and performance of beef heifers supplemented with mineral or protein/energy supplement, maintained on Brachiaria brizantha cv. Marandu pasture subjected to different grazing intensities under continuous stocking during the rainy season, and each of them had a body weight of approximately $300 \mathrm{~kg}$, forming a homogeneous group. The animals were initially housed for a 25-d adaptation period to adapt to the facilities, management and diet. After this period, they were randomly allocated to individual stalls.

The experimental diets were formulated to provide a dry matter (DM) intake of $23.0 \mathrm{~g} / \mathrm{kg}$ of body weight and gain of $1.20 \mathrm{~kg} / \mathrm{d}$, which was obtained by the RLM Software ${ }^{\circledR} /$ ESALQ-USP (1999) according to the CNCPS system developed by Fox et al. (1992).

The diets were isocaloric and isonitrogenous and were composed of corn silage for roughage $(600 \mathrm{~g} / \mathrm{kg})$ and concentrate mixture $(400 \mathrm{~g} / \mathrm{kg})$. The diets were based on maize and soybean meal and supplemented with a mineral mix (Table 1). In the soybean diet, the soybeans were the main protein source replacing all the soybean meal.

Ingredients were ground in a hammer mill fitted with strainers and $5 \mathrm{~mm}$ sieves. The mixture homogenization was performed in a horizontal mixer for $15 \mathrm{~min}$.

Animals were fed corn roughage and the experimental concentrates once a day at 8:30 a.m. Throughout the entire experimental period, the provided quantities were adjusted to allow approximately $10 \%$ surplus in relation to the total consumed the previous day to provide intake ad libitum.

The leftovers were removed and weighed every three days, and then grouped in periods of $34 \mathrm{~d}$ and placed in a freezer at $-20^{\circ} \mathrm{C}$. After the experimental period, the samples were thawed and grouped per animal and per period. Subsequently, they were freeze-dried, ground $(1 \mathrm{~mm})$ and analyzed. To estimate the nutrient intake of the animals, the
Table 1 - Chemical composition of the ingredients and initial formulation (DM g/kg) of experimental diets

\begin{tabular}{|c|c|c|c|}
\hline & \multicolumn{3}{|c|}{ Chemical composition (g/kg) } \\
\hline & Dry matter & Crude protein & NDF \\
\hline Corn silage & 348.0 & 77.00 & 571.0 \\
\hline Soy grain feed (SG) & 881.0 & 216.0 & 153.0 \\
\hline Protected fat feed (PF) & 882.0 & 226.0 & 135.0 \\
\hline \multirow[t]{2}{*}{ Soybean oil feed (SO) } & 870.0 & 223.0 & 134.0 \\
\hline & \multicolumn{3}{|c|}{ Diets（g/kg） } \\
\hline Ingredients & SG & $\mathrm{PF}$ & $\mathrm{SO}$ \\
\hline Corn silage & 600.0 & 600.0 & 600.0 \\
\hline Megalac-E ${ }^{\circledR}$ & 000.0 & 32.00 & 000.0 \\
\hline Soybean & 140.0 & 000.0 & 000.0 \\
\hline Soybean meal & 000.0 & 128.0 & 124.0 \\
\hline Soybean oil & 000.0 & 000.0 & 26.00 \\
\hline Ground corn & 240.0 & 220.0 & 230.0 \\
\hline \multirow[t]{2}{*}{ Mineral suplement ${ }^{1}$} & 20.00 & 20.00 & 20.00 \\
\hline & Chemical compos & tion of total die & $(\mathrm{g} / \mathrm{kg})$ \\
\hline Dry matter & 561.0 & 561.0 & 557.0 \\
\hline Organic matter & 949.0 & 941.0 & 948.0 \\
\hline Mineral matter & 51.00 & 59.00 & 52.00 \\
\hline Crude protein & 132.0 & 136.0 & 135.0 \\
\hline Ether extract & 58.00 & 58.00 & 58.00 \\
\hline Neutral detergent fiber & 404.0 & 397.0 & 396.0 \\
\hline Acid detergent fiber & 203.0 & 200.0 & 200.0 \\
\hline Lignin & 45.00 & 44.00 & 49.00 \\
\hline Net energy (kcal/g) & 4.600 & 4.600 & 4.700 \\
\hline
\end{tabular}

SG - diet containing $60 \%$ corn silage and $40 \%$ concentrate based on soybeans as fat source; PF - diet containing $60 \%$ corn silage and $40 \%$ concentrate based on protected fat (Megalac- $\mathrm{E}^{\circledR}$ ) as fat source; SO - diet containing $60 \%$ corn silage and $40 \%$ concentrate based on soybean oil as fat source; DM - dry matter; NDF neutral detergent fiber.

${ }^{1}$ Composition of product (calcium - $45 \mathrm{~g}$; phosphorus - $12 \mathrm{~g}$; magnesium - $46 \mathrm{~g}$; sulfur - $14 \mathrm{~g}$; sodium - $58 \mathrm{~g}$; copper - $140 \mathrm{mg}$; manganese - $410 \mathrm{mg}$; zinc - $525 \mathrm{mg}$; iodine - $10 \mathrm{mg}$; cobalt - $8 \mathrm{mg}$; selenium - $2.5 \mathrm{mg}$; fluorine (max.) - $120 \mathrm{mg}$; monensin - $400 \mathrm{mg}$ )

samples were analyzed for the following components: dry matter, organic matter, ether extract and crude protein according to the AOAC (1990); and neutral detergent fiber (NDF) and acid detergent fiber (ADF) according to Van Soest \& Robertson (1985) with the samples subjected to digestion in detergent solution for 40 minutes in an autoclave at $111^{\circ} \mathrm{C}$ and $0.5 \mathrm{~atm}$ (Deschamps, 1999). The gross energy (GE) was obtained through sample combustion in an adiabatic calorimetric bomb (PARR Instruments).

After $68 \mathrm{~d}$ of confinement, the animals were transported to a slaughter house. The next day, after fasting (solids) for $24 \mathrm{~h}$, slaughter took place using a compressed air pistol to cause a cerebral concussion, and the animals were then bled by cutting the jugular and carotid veins.

After slaughter, carcasses were identified and weighed to obtain the weight and hot carcass yield. Carcass yield was calculated with the hot carcass weight and body weight ratio after fasting. After cooling for $24 \mathrm{~h}$ in a refrigerator at $4{ }^{\circ} \mathrm{C}$, carcasses were weighed again to obtain the cold carcass weight. The $\mathrm{pH}$ was measured with a digital meter, and carcasses were evaluated according to the procedures described by Muller (1987). 
A cross-section from the left half of the carcass, including the 9th, 10th and 11th ribs that compose the second section, Hankins \& Howe section (HH), was removed for assessment of body composition according to Hankins \& Howe (1946). The assessment consisted of weighing the cut and visual separation of the muscle, fat and bones with a knife, which were weighed separately for the calculations of each component (kg/100 kg of carcass).

After the section dissection, the equations proposed by Hankins \& Howe (1946) were used to predict the muscle, fat and bone proportions in the carcass. The following recommended equations were used:

Muscle proportion (MP): $\mathrm{Y}=16.08+0.80 \mathrm{X}$

Adipose tissue proportion (ATP): $\mathrm{Y}=3.54+0.80 \mathrm{X}$

Bone proportion (BP): $\mathrm{Y}=5.52+0.57 \mathrm{X}$

where $\mathrm{X}=$ component percentage in the $\mathrm{HH}$ section obtained in the cold room.

In the right half of the carcass, the carcass length, leg length, thigh thickness, shin length, shin width and carcass width were measured. The primary cuts were also separated into rear, front and spare ribs. They were all weighed to calculate percentages in relation to the half carcass.

The experimental design was completely randomized with 21 animals, 3 treatments and 7 replications. Statistical analysis was conducted with the GLM procedure of SAS (Statistical Analysis Sytem, version 9.1). The initial body weight was used as a co-variable for the statistical analyses of the average daily weight gain, slaughter weight and nutrient intake. When necessary, treatment means were compared using the Tukey test and adopting $\alpha=0.05$.

\section{Results and Discussion}

The fat supplements significantly affected $(\mathrm{P}<0.05)$ the intake of all studied nutrients. Soybean and soybean oil resulted in reductions ( $11.48 \%$ and $10.45 \%$, respectively) of DM intake when compared with protected fat, which had greater DM intake and percentage of body weight (Table 2).

One possible explanation for the reduced intake in the soybean oil and grain is the theory of intake regulation proposed by Nicholson \& Omer (1983). This theory suggests that the increase in cholecystokinin secretion due to the presence of UFA in the digestion may inhibit motility in the rumen and reticulum reducing the feed intake.

A negative effect of oil intake was also observed by Jenkins \& Palmquist (1984). This occurs because rich sources of UFA, such as soybean oil, have effects on the microbial membrane permeability, primarily by inhibiting the Gram-positive bacteria activity, where this alters the rumen fermentation (Nagaraja et al., 1997). Thus, adhesion and multiplication of the cellulolytic bacteria population responsible for fiber fermentation is prevented, thereby reducing feed passage through the digestive system and, consequently, intake.

According to McNiven et al. (2004), soybeans are rich in UFAs and are used in diets to increase the amount of lipids, which increases the flow of UFAs into the small intestine. According to Martinez Marin (2007), approximately $20 \%$ of UFA ingested by ruminants reach the small intestine without undergoing complete biohydrogenation. However, increased or decreased UFA flow into the small intestine depends on the lipid source used and the diet composition (Jordan et al., 2006).

The current literature is not conclusive regarding the effects of protected fat on nutrient intake. Allen (2000) developed equations involving 24 studies on protected fat and suggested that the addition of $1 \mathrm{~g} / \mathrm{kg}$ protected fat reduces the DM intake by $2.5 \mathrm{~g} / \mathrm{kg}$. Other studies reported no effect with the supplementation of protected fat on the DM intake of cows and sheep (Palmquist, 1991; Perez Alba et al., 1997).

Working with pregnant goats, Silva et al. (2007) tested different lipid sources, such as soybeans, soybean oil and

Table 2 - Nutrient intake of crossbred heifers slaughtered in confinement receiving different fat sources

\begin{tabular}{|c|c|c|c|c|c|}
\hline \multirow[b]{2}{*}{ Daily intake } & \multicolumn{3}{|c|}{ Diet } & \multirow[b]{2}{*}{$\mathrm{P}$ value } & \multirow[b]{2}{*}{$\mathrm{CV}$} \\
\hline & SG & GP & OS & & \\
\hline DM (kg of animal/d) & $7.790 \mathrm{~b}$ & $8.800 \mathrm{a}$ & $7.880 \mathrm{~b}$ & $<0.001$ & 7.900 \\
\hline DM (g/kg of body weight) & $22.10 \mathrm{~b}$ & $24.00 \mathrm{a}$ & $22.00 \mathrm{~b}$ & 0.002 & 6.710 \\
\hline OM (kg of animal/d) & $7.380 \mathrm{~b}$ & $8.260 \mathrm{a}$ & $7.460 \mathrm{~b}$ & $<0.001$ & 7.850 \\
\hline CP (kg of animal/d) & $1.050 \mathrm{~b}$ & $1.190 \mathrm{a}$ & $1.060 \mathrm{~b}$ & 0.005 & 10.15 \\
\hline EE (kg of animal/d) & $0.510 \mathrm{~b}$ & $0.570 \mathrm{a}$ & $0.500 \mathrm{~b}$ & $<0.001$ & 8.860 \\
\hline NDF (kg of animal/d) & $2.750 \mathrm{~b}$ & $3.430 \mathrm{a}$ & $3.060 \mathrm{~b}$ & 0.001 & 14.62 \\
\hline NDF (g/kg of body weight) & $8.019 b$ & $9.124 \mathrm{a}$ & $8.564 b$ & 0.046 & 10.78 \\
\hline
\end{tabular}


protected fat (Megalac- $E^{\circledR}$ ). They suggested that the Megalac- $E^{\circledR}$-protected fat proportionally presents more UFA than previous formulations of protected fat. Thus, the involvement of UFA in this supplement is greater than in soybean oil.

Chelikàni et al. (2004) stated that when ruminants are fed large amounts of unsaturated fats, feed intake is reduced. The hypophagic effects in which lipid supplementation reduces intake, as mentioned by Allen (2000), involve rumen fermentation, intestinal motility, diet palatability, gut hormone release and liver fat oxidation. This implicates that the mechanism of physiological regulation may justify the greater intake of the diet with protected fat when compared with the diet with other lipid supplements.

Aferri et al. (2005) found similar DM intake values calculated as percentage of body weight. They fed 14-monthold confined crossbreed steers with diets containing either $5 \mathrm{~g} / \mathrm{kg}$ fatty acid calcium salts or $21 \mathrm{~g} / \mathrm{kg}$ cottonseed, and the DM intake values were $2.45 \mathrm{~g} / \mathrm{kg}$ and $2.29 \mathrm{~g} / \mathrm{kg}$, respectively.

Nutrient intake was influenced by the lipid sources, and the animals that received protected fat ingested greater $(\mathrm{P}<0.05)$ amounts of OM, CP, EE, and NDF. This was due to greater DM intake and, consequently, greater nutrient intake when compared with the other diets.

Lipid sources influence the average daily weight gain $(\mathrm{P}<0.05)$, but significant differences were not found in the protein efficiency ratio and feed conversion ( $\mathrm{P}>0.05$; Table 3 ). Average feed conversion and protein efficiency ratio values were $5.68 \mathrm{~kg} \mathrm{DM} / \mathrm{kg}$ weight gain and $1.38 \mathrm{~kg}$ weight gain $/ \mathrm{kg}$ protein intake, respectively.

According to Mannetje (1982), in cattle production systems solely based on pasture, the genetic potential to gain weight, especially of larger body size, is never reached. The maximal daily live weight gain obtained in these circumstances corresponds to approximately half of the

Table 3 - Average daily weight gain (ADG; kg/animal/d), feed conversion (FC; kg DM/kg weight gain) and protein efficiency ratio (PER; kg weight gain/kg protein intake) of crossbred heifers slaughtered in confinement receiving different lipid sources

\begin{tabular}{|c|c|c|c|c|c|}
\hline \multirow[b]{2}{*}{ Variable } & \multicolumn{3}{|c|}{ Diet } & \multirow[b]{2}{*}{$\mathrm{P}$ value } & \multirow[b]{2}{*}{$\mathrm{CV}$} \\
\hline & SG & $\mathrm{PF}$ & SO & & \\
\hline ADG & $1.390 \mathrm{~b}$ & $1.710 \mathrm{a}$ & $1.420 \mathrm{~b}$ & 0.042 & 17.35 \\
\hline FC & 5.710 & 5.440 & 5.910 & 0.451 & 18.90 \\
\hline PER & 1.350 & 1.430 & 1.360 & 0.673 & 14.54 \\
\hline
\end{tabular}

SG - diet containing $60 \%$ corn silage and $40 \%$ concentrate based on soybeans as fat source; GP - diet containing $60 \%$ corn silage and $40 \%$ concentrate based on protected fat (Megalac- $\mathrm{E}^{\circledR}$ ) as fat source; OS - diet containing 60\% corn silage and $40 \%$ concentrate based on soybean oil as fat source; CV - coefficient of variation (\%).

a, b - means followed by different lowercase letters in the same row differ $(\mathrm{P}<0.05)$ according to Tukey test. genetic potential of the animal. This may help to explain the compensatory growth effect of the animals in this study. Although the animals were coming from pasture and receiving supplementation, it may not have been enough to reach the potential maximal weight gain of the animals.

The compensatory weight gain effect is not well understood. More information is needed to incorporate the weight gain effect efficiently in prediction or performance models. The main problem involves the correct identification of each factor that affects compensatory growth, and understanding the biological processes that trigger compensatory growth also poses a challenge.

Weight gain differences occur because the feed efficiency of the animals decreases as they grow. The nutritional requirements for maintenance increase because it is a characteristic associated with body weight; furthermore, adipose tissue requires 2.5 times more nutrition.

Fernandes et al. (2007) fed Canchim heifers in confinement with two different diets. One diet was composed of sugar cane and sunflower seed, and the other diet was based on corn silage and soybean meal. They found an average daily weight gain of $1.32 \mathrm{~kg}$ and feed conversion of $5.81 \mathrm{~kg} \mathrm{DM} / \mathrm{kg}$ weight gain.

Jaeger \& Oliveira (2007) fed 14-month-old male bulls diets with $5 \%$ protected fat (LAC-100 Yakult ${ }^{\circledR}$ based on soybean oil complexed with calcium) and found average daily weight gain values of $1.47 \mathrm{~kg}$ and feed conversion values of $7.08 \mathrm{~kg} \mathrm{DM} / \mathrm{kg}$. These results are lower than the results found in the present study.

Similarily, Aferri et al. (2005) found average daily weight gain values of $1.17 \mathrm{~kg} / \mathrm{d}$ and feed conversion values of $8.38 \mathrm{~kg}$ of DM/kg in diets with $5 \%$ calcium salts and the addition of fatty acids. They also reported average daily weight gain values of $1.20 \mathrm{~kg} / \mathrm{d}$ and feed conversion values of $7.86 \mathrm{~kg}$ DM/kg gain in diets with $21 \mathrm{~g} / \mathrm{kg}$ cottonseed. Moreover, Putrino et al. (2006) found greater weight gains with less DM intake in confined Nellore heifers fed with protected fat (Lacto Plus ${ }^{\circledR}$ produced from vegetable fat soy).

Protein is the nutrient of greatest cost in feed and represents most of the production cost in confinement systems. Therefore, it is important to identify the efficiency of protein. Although the protein efficiency ratio did not have differences between treatments $(\mathrm{P}>0.05)$, the animals fed protected fat had a numerically greater average of $5.25 \mathrm{~g} / \mathrm{kg}$ compared with other lipid sources.

There was no difference $(\mathrm{P}>0.05)$ between the initial animal weights. However, the difference was used as a covariable in the slaughter weight. The slaughter weight was different $(\mathrm{P}<0.05)$ among the various treatments (Table 4). 
With greater feed intake and, consequently, superior performance, the animals fed protected fat had greater average slaughter weight and were $5 \%$ heavier than the animals fed other treatments.

Animals receiving the diet with protected fat showed an average gain of $18 \%$ greater than the animals fed the other diets. The greater weight gains observed in the diets is attributed to the energy values of the diets and the genetic quality of the heifers because they were derived from industrial crosses of second generations.

The hot carcass weight, hot carcass yield, cold carcass weight, cold carcass yield and $\mathrm{pH}$ characteristics $24 \mathrm{~h}$ after slaughter were not different between the various treatments $(\mathrm{P}>0.05)$.

Carcass traits are influenced by nutritional management, age at slaughter, genetic factors and sexual condition. Restle et al. (2001) examined the carcasses of slaughtered confined heifers ( $3 / 4$ Charolais $\times 1 / 4$ Nellore) and found a hot carcass yield of $51.6 \mathrm{~kg} / 100 \mathrm{~kg}$, which was a value similar to those observed in the present study.

The hot carcass yield had an average value of $50.78 \mathrm{~kg} /$ $100 \mathrm{~kg}$. The following similar values were found in other studies: $51.4 \mathrm{~kg} / 100 \mathrm{~kg}$ was observed by Restle et al. (2001) for $3 / 4$ Charolais $\times 1 / 4$ Nellore heifers; $51.4 \mathrm{~kg} / 100 \mathrm{~kg}$ was observed by Kazama et al. (2008) for $1 / 2$ Nellore $\times 1 / 2$ Angus heifers. Furthermore, Marques et al. (2000) observed a value of $50.9 \mathrm{~kg} / 100 \mathrm{~kg}$ in approximately 24 -month-old crossbreed heifers (Angus $\times$ Nellore and Simmental $\times$ Nellore) fed diets of corn replaced by cassava husk, cassava meal or cassava.
The same authors mentioned that this value $(50.9 \mathrm{~kg} / 100 \mathrm{~kg})$ was below the normal for this animal category in which the yield between $52 \mathrm{~kg} / 100 \mathrm{~kg}$ and $54 \mathrm{~kg} / 100 \mathrm{~kg}$ is considered satisfactory depending on the cold room with characteristics of carcass cleaning according to the different market requirements.

However, no effects on yields and carcass weights were observed in various studies including the study done by Jaeger et al. (2004). They used four different genetic groups fed diets either with or without protected fat. Furthermore, Aferri et al. (2005) found no effects on yields and carcass weights when animals were provided with three different diets including a diet containing cottonseed, one with protected fat and one without protected fat.

Differences in carcass yield are more commonly described in experiments conducted with various genetic types of cattle (Chambaz et al., 2003), and these studies show different tissue growth curves, and different slaughter and trim conditions. Also, according to Reis \& Lobo (1991), genetic variants and independent environments do not exist with regard to animal performance in the broad sense.

Carcass growth characteristics (carcass length, leg length, shin length, shin circumference, carcass width and thigh thickness) were not influenced by the different lipid sources tested (Table 4; $\mathrm{P}>0.05$ ).

The carcass measurements serve to characterize the product, thereby presenting a high correlation with their weight and can be used as indicators of carcass traits.

Table 4 - Characteristics of carcass of crossbred heifers slaughtered in confinement receiving different lipid sources

\begin{tabular}{|c|c|c|c|c|c|}
\hline \multirow[t]{2}{*}{ Variable } & \multicolumn{3}{|c|}{ Diets } & \multirow[b]{2}{*}{$\mathrm{P}$ value } & \multirow[b]{2}{*}{$\mathrm{CV}$} \\
\hline & SG & $\mathrm{PF}$ & SO & & \\
\hline IW (kg) & 303.4 & 304.1 & 303.9 & 0.241 & 12.61 \\
\hline HCW (kg) & 204.1 & 211.4 & 203.1 & 0.320 & 5.182 \\
\hline HCY (kg/100 kg) & 51.29 & 50.39 & 50.68 & 0.734 & 3.901 \\
\hline CCW (kg) & 200.2 & 207.3 & 199.5 & 0.311 & 5.014 \\
\hline CL (cm) & 124.9 & 124.1 & 123.7 & 0.771 & 2.425 \\
\hline $\mathrm{LL} \quad(\mathrm{cm})$ & 69.32 & 67.63 & 67.48 & 0.330 & 3.394 \\
\hline $\mathrm{SL}(\mathrm{cm})$ & 41.77 & 41.17 & 40.77 & 0.382 & 3.022 \\
\hline $\mathrm{SC}(\mathrm{cm})$ & 33.58 & 34.62 & 35.08 & 0.721 & 9.550 \\
\hline $\mathrm{CW}(\mathrm{cm})$ & 38.59 & 37.54 & 38.94 & 0.190 & 3.713 \\
\hline $\mathrm{TT}(\mathrm{cm})$ & 25.02 & 25.75 & 25.08 & 0.680 & 6.524 \\
\hline
\end{tabular}


These characteristics are also indicative of the size and are related to race and age of animals. Carcass length is directly related to the bone tissue development when they are evaluated and, hence the animal growth phase. Thigh thickness is one of the most important factors in quantifying carcass muscle. Along with shin circumference, the thigh thickness indicates muscle yield.

Marques et al. (2006) observed average values of $113.8 \mathrm{~cm}, 68.4 \mathrm{~cm}$ and $21.1 \mathrm{~cm}$ in carcass length, leg length and thigh thickness, respectively. In their study, they used 18 -month-old confined crossbreed heifers $(1 / 2$ Nellore $\times 1 / 2$ Red Angus) subjected to surgical or mechanical anestrous that were fed a diet based on corn silage (41\%) and soybean meal with corn (59\%).

According to Viljoen et al. (2002), the pH values obtained $24 \mathrm{~h}$ after slaughter should be below 5.80 (Table 4). They suggest that above this value, the meat should be classified as dark, firm and dry, and the rejection of this kind of meat by consumers is higher. Thus, the average value (5.76) obtained in this study was within the ideal $\mathrm{pH}$ range because Brazilian slaughterhouses export only beef with $\mathrm{pH}$ below 5.8, which is directly assessed in the longissimus dorsi muscle $24 \mathrm{~h}$ postmortem (Oliveira et al., 2009).

The loin eye area (LEA) is an objective measure of great value in predicting the amount of carcass muscle. The muscles of late maturity represent the most reliable index of development and muscle tissue size, so the longissimus muscle is the most suitable because it matures late and is easily measured (Osório \& Osório, 2005).

No significant differences $(\mathrm{P}>0.05)$ were observed between the LEA values in the present study. The average rib eye area found $\left(71.23 \mathrm{~cm}^{2}\right)$ was considered satisfactory in 18-month-old females because this characteristic is determined by various factors, such as sex (Müller et al., 2005), age (Marques et al., 2006), race (Moreira et al., 2005), size and weight of the animal (Costa et al., 2002; Abrahão et al., 2005). According to Marques et al. (2006), males that are older, heavier and larger typically have greater LEAs.

Marques et al. (2006) found lower values $\left(57.30 \mathrm{~cm}^{2}\right)$ in 18-month-old crossbred heifers. Moreover, Abrahão et al. (2005) observed mean LEA values of $63.17 \mathrm{~cm}^{2}$ and $70.91 \mathrm{~cm}^{2}$ in crossbred females receiving corn meal or dried cassava starch, respectively.

The measure of the LEA expressed in relation to cold carcass weight (LEA/100 kg cold carcass; relative LEA) allows a better interpretation of the information concerning the rib eye area and, therefore, facilitates the identification of animals with superior muscularity. There were no differences $(\mathrm{P}>0.05)$ in the relative LEA as a function of the studied lipid sources. In this study, an average relative LEA of $35.54 \mathrm{~cm}^{2} / 100 \mathrm{~kg}$ of carcass was obtained, which was above the value recommended by Luchiari Filho (2000), who recommends that the relative LEA be at least $29 \mathrm{~cm}^{2} / 100 \mathrm{~kg}$ of carcass. This value is a reference because as the LEA increases, so does the edible portion, which means that this value an indicator of muscle development.

Aferri et al. (2005) also observed no differences in LEA $\left(\mathrm{cm}^{2}\right)$ and relative LEA $\left(\mathrm{cm}^{2} / 100 \mathrm{~kg}\right.$ of carcass) with confined 14-month-old crossbred heifers fed diets containing different lipid sources (5 g/kg fatty acid calcium salts or $21 \mathrm{~g} / \mathrm{kg}$ cottonseed). The averages found in the reported study were $71.5 \mathrm{~cm}^{2}$ and 29.8 relative LEA for diets with $5 \mathrm{~g} / \mathrm{kg}$ fatty acid calcium salts and $66.9 \mathrm{~cm}^{2}$ and $28 \mathrm{~cm}^{2} / 100 \mathrm{~kg}$ of carcass (relative LEA) in diets with $21 \mathrm{~g} / \mathrm{kg}$ cottonseed.

The subcutaneous fat thickness did not differ $(\mathrm{P}>0.05)$ in the animals with different treatments. Vaz et al. (2001) worked with Charolais males and crossbred males (3/4 Charolais $\times$ $1 / 4$ Nellore) with a slaughter age of two years. These authors found average fat thickness of $2.2 \mathrm{~mm}$ and $2.8 \mathrm{~mm}$, respectively, in the genetic groups tested. These results suggest that large animals take longer to deposit fat. In addition to other factors, this characteristic is influenced by physiological maturity, adult size of the animal, sex and energy density of the diet. As the Brazilian market requires values from $3.0 \mathrm{~mm}$ to $6.0 \mathrm{~mm}$, the average values of this study $(6.4 \mathrm{~mm})$ met the market requirements.

According to Luchiari Filho (2000), there is a negative correlation between fat thickness and coverage of edible portion because the greater fat thickness values lowers the LEA value. Thus, the subcutaneous fat in small amounts causes problems in carcass handling and sarcomere shortening during storage due to cold temperatures. Moreover, high levels of lipid sources are not only undesirable but also decrease the edible portion yield. Therefore, they need to be trimmed before marketing, which results in waste.

Significant differences $(\mathrm{P}<0.05)$ were found in the bone proportion and adipose tissue proportion characteristics (Table 5).

Animals that received the soybean diet had a greater bone proportion $(15.22 \mathrm{~kg} / 100 \mathrm{~kg}$ of carcass) than the animals fed protected fat (13.79 kg/100 kg of carcass). In terms of adipose tissue proportion, protected fat resulted in a greater value (32.02 kg/100 kg of carcass) when compared with the value $(25.84 \mathrm{~kg} / 100 \mathrm{~kg}$ of carcass) resulting from the soybean diet. The muscle proportion did not change with different treatments.

The fat, muscle and bone proportions of animals are of great interest to the producer, industry and, in particular, the consumer (Hankins \& Howe, 1946). As the slaughter period progresses, the weight gain composition is changed 
so that the initial growth, predominantly muscle, gives rise to a greater retention of energy as fat. This process is mainly influenced by the nutritional level and occurs more sharply for the fat and protein ratio (Di Marco, 1998).

Marques et al. (2006) worked with 18-month-old confined crossbred heifers ( $1 / 2$ Nellore $\times 1 / 2$ Red Angus) that underwent surgical or mechanical anestrous and were given a diet based on corn silage (41\%) and soybean meal with corn (59\%). They found greater values of bone proportion (16.0 kg/100 kg of carcass) and muscle proportion (62.6 kg/ $100 \mathrm{~kg}$ of carcass) and lower values of adipose tissue proportion (20.9 kg/100 kg of carcass) when compared with the values of the present study. Similiarly, Vaz \& Restle (2003) observed greater muscle proportion $(69.60 \mathrm{~kg} / 100 \mathrm{~kg}$ of carcass) in animals that had lower carcass fat percentages (14.60 kg/100 kg of carcass).

Carcasses with greater muscle quantity and less fat are ideal because the cleaning process is less pronounced, which reduces waste and increases the carcass yield.

Ribeiro et al. (2001) stated that greater hindquarter yields are economically desirable because the best parts of the carcass are found in the hindquarter; thus achieving greater business value. In this study, however, no significant differences $(\mathrm{P}>0.05)$ were found in yields when comparing hindquarters, forequarters and spare ribs with the different diets (Table 5).

Fernandes et al. (2008) worked with confined Canchim heifers and observed similar yield values from hindquarters, forequarters and spare ribs (52.78, 34.71 and $11.92 \mathrm{~kg} / 100$ $\mathrm{kg}$ of carcass, respectively).

Junqueira et al. (1998) did not observe differences with respect to the hindquarter yield between intact males and heifers. However, the same authors found that females had a lower forequarter yield. These observations are associated with the growth characteristics of animals with different genders. Moreover, uncastrated males have greater muscle tissue development in the forequarter than castrated animals and females (Fernandes et al., 2008). According to Luchiari Filho (2000), this differential growth is influenced by the presence of gonadotrophic androgens, which are needed to fully complete the muscle development patterns.

Table 5 - Bone proportion (BP), muscle proportion (MP), adipose tissue proportion (ATP), special hindquarter yield (SHY), forequarter yield (FY) and spare rib performance (SRP) of crossbred heifers in confinement fed different lipid sources

\begin{tabular}{|c|c|c|c|c|c|}
\hline \multirow[t]{2}{*}{ Variable } & \multicolumn{3}{|c|}{ Diet ${ }^{1}$} & \multirow[b]{2}{*}{$\mathrm{P}$ value } & \multirow[b]{2}{*}{$\mathrm{CV}$} \\
\hline & SG & $\mathrm{PF}$ & SO & & \\
\hline BP (kg/100 kg of carcass) & $15.22 \mathrm{a}$ & $13.79 b$ & $14.42 \mathrm{ab}$ & 0.042 & 6.560 \\
\hline MP (kg/100 kg of carcass) & 60.16 & 55.98 & 58.85 & 0.081 & 5.501 \\
\hline ATP (kg/100 kg of carcass) & $25.84 b$ & $32.02 \mathrm{a}$ & $28.27 \mathrm{ab}$ & 0.011 & 11.30 \\
\hline SHY (kg/100 kg of carcass) & 53.24 & 52.28 & 53.13 & 0.090 & 1.542 \\
\hline FY (kg/100 kg of carcass) & 35.45 & 35.68 & 35.17 & 0.561 & 2.482 \\
\hline SRP (kg/100 kg of carcass) & 11.31 & 12.04 & 11.70 & 0.121 & 4.96 \\
\hline
\end{tabular}

SG - diet containing $60 \%$ corn silage and $40 \%$ concentrate based on soybeans as fat source; PF - diet containing $60 \%$ corn silage and $40 \%$ concentrate based on protected fat (Megalac-E®) as fat source; SO - diet containing $60 \%$ corn silage and $40 \%$ concentrate based on soybean oil as fat source; CV - coefficient of variation (\%).

a, b Means followed by different lowercase letters in the same row differ according to the Tukey test $(\mathrm{P}<0.05)$.

\section{Conclusions}

Protected fat provides a greater nutrient intake and increases the average daily weight gain of heifers. The use of the energy fraction (oil) from soy in the form of protected fat (calcium salts) promotes a better trimming of the carcasses. Lipid sources do not influence the feed conversion or protein efficiency ratios of the animals.

\section{Acknowledgements}

The authors thank the Research Support Foundation of São Paulo (FAPESP) for financing the research.

\section{References}

ASSOCIATION OF ANALITICAL CHEMIST - AOAC. Official methods of analysis. 15.ed. Arlington: 1990. 1117p.
ABRAHÃO, J.J.S.; MACEDO, L.M.A.; PEROTTO, D. et al. Características de carcaça de novilhas mestiças confinadas, submetidas a dietas com milho ou resíduo seco de fecularia de mandioca. Acta Scienciarum.Animal Sciences, v.27, p.459-468, 2005.

AFERRI, G.; LEME, P.R.; SILVA, S.L. et al. Desempenho e características de carcaça de novilhos alimentados com dietas contendo diferentes fontes de lipídios. Revista Brasileira de Zootecnia, v.34, p.1651-1658, 2005.

ALLEN, M.S. Effects of diet on short-term regulation of feed intake by lactating dairy cattle. Journal of Dairy Science, v.83, p.1598-1624, 2000.

BATEMAN II, H.G.; JENKINS, T.C. Influence of soybean oil in high fiber diets fed to nonlactating cows on ruminal unsaturated fatty acids and nutrient digestibility. Journal of Dairy Science, v.81, p.2451-2458, 1998.

CHAMBAZ, A.; SCHEEDER, M.R.L.; KREUZER, M. et al. Meat quality of Angus, Simmental, Charolais and Limousin steers compared at the same intramuscular fat content. Meat Science, v.63, p.491-500, 2003.

CHELIKÀNI, P.K.; BELL, J.A.; KENNELLY, J.J. Effects of feeding or abomasal infusion of canola oil in Holstein cows. 1. Nutrient 
digestion and milk composition. Journal of Dairy Research, v.71, p.279-287, 2004.

COSTA, E.C.; RESTLE, J.; VAZ, F.N. et al. Características da carcaça de novilhos Red Angus superprecoces abatidos com diferentes pesos. Revista Brasileira de Zootecnia, v.31, p.119-128, 2002.

DEMEYER, D.; DOREAU, M. Targets and procedures for altering ruminant meat and milk lipids. Proceedings of the Nutrition Society, v.58, p.593-607, 1999.

DESCHAMPS, F.C. Implicações do período de crescimento na composição química e digestão dos tecidos de cultivares de capim elefante. Revista Brasileira de Zootecnia, v.28, p.1178-1189, 1999.

DI MARCO, O.N. Crecimiento de vacunos para carne. Buenos Aires: Oscar N. DiMarco, 1998. 246p.

FERNANDES, A.R.M.; SAMPAIO, A.A.M.; HENRIQUE, W. et al. Características da carcaça e da carne de bovinos sob diferentes dietas, em confinamento. Arquivo Brasileiro de Medicina Veterinária e Zootecnia, v.60, p.139-147, 2008.

FERNANDES, A.R.M.; SAMPAIO, A.A.M.; HENRIQUE, W. et al. Avaliação econômica e desempenho de machos e fêmeas Canchim em confinamento alimentados com dietas à base de silagem de milho e concentrado ou cana-de-açúcar e concentrado contendo grãos de girassol. Revista Brasileira de Zootecnia, v.36, p.855-864, 2007.

FOX, D.G.; SNIFFEN, C.J.; O'CONNOR, J.D. et al. A net carbohydrate and protein system for evaluating cattle diets: III. Cattle requirements and diets adequacy. Journal of Animal Science, v.70, p.3578-3596, 1992.

HANKINS, O.G.; HOWE, P.E. Estimation of the composition of beef carcasses and cuts. [T.B.]: United States Department of Agriculture, 1946. p.1-19. (Technical Bulletin, 926).

HARVATINE, K.J.; ALLEN, M.S. Fat supplements affect fractional rates of ruminal fatty acid biohydrogenation and passage in dairy cows. Journal of Nutrition, v.136, p.677-685, 2006.

JAEGER, S.M.P.L.; OLIVEIRA, R.L. Uso de gordura protegida sobre o desempenho e a digestibilidade para diferentes grupos genéticos de bovinos em confinamento. Magistra, v.19, p.135-142, 2007.

JAEGER, S.M.P.L.; DUTRA, A.R.; PEREIRA, J.C. et al. Características da carcaça de bovinos de quatro grupos genéticos submetidos a dietas com ou sem adição de gordura protegida. Revista Brasileira de Zootecnia, v.33, p.1876-1887, 2004.

JENKINS, T.C.; PALMQUIST, D.L. Effect of fatty acids or calcium soaps on rumen and total nutrient digestibility of dairy rations. Journal of Dairy Science, v.67, p.978-986, 1984.

JORDAN, E.; KENNY, D.; HAWKINS, M. et al. Effect of refined soy oil or whole soybeans on intake, methane output, and performance of young bulls. Journal of Animal Science, v.84, p.2418-2425, 2006.

JUNQUEIRA, J.O.B.; VELLOSO, L.; FELÍCIO P.E. Desempenho, rendimentos de carcaça e cortes de animais, machos e fêmeas, mestiços marchigiana $\mathrm{x}$ nelore, terminados em confinamento. Revista Brasileira de Zootecnia, v.27, p.1119-1205, 1998.

KAZAMA, R.; ZEOULA, L.M.; PRADO I.N. et al. Características quantitativas e qualitativas da carcaça de novilhas alimentadas com diferentes fontes energéticas em dietas à base de cascas de algodão e de soja. Revista Brasileira de Zootecnia, v.37, p.350-357, 2008.

LUCHIARI FILHO, A. Pecuária da carne bovina. São Paulo: LinBife, 2000. 134p.

MANNETJE, L.T. Problems of animal production from tropi-cal pastures. In: HACKER, J.B. (Ed.). Nutritional limits to animal production from pastures. Commonwealth Agricultural Bureaux, Farnham Royal, 1982. p.67-86.

MARQUES, J.A.; PRADO, I.N.; MOLETTA, J.L. et al. Características físico-químicas da carcaça e da carne de novilhas submetidas ao anestro cirúrgico ou mecânico terminadas em confinamento. Revista Brasileira de Zootecnia, v.35, p.1514-1522, 2006.
MARQUES, J.A.; PRADO, I.N.; ZEOULA, L.M. et al. Avaliação da mandioca e seus resíduos industriais em substituição ao milho no desempenho de novilhas confinadas. Revista Brasileira de Zootecnia, v.29, p.1528-1536, 2000.

MARTINEZ MARÍN, A.L. Influencia de la nutrición sobre elcontenido y tipo de ácidos grasos en la carne de los rumiantes. Archivos de Zootecnia, v.56, p.45-66, 2007.

McNIVEN, M.A.; DUYNISVELD, J.; CHARMLEY, E. et al. Processing of soybean affects meat fatty acid composition and lipid peroxidation in beef cattle. Animal Feed Science and Technology, v.116, p.175-184, 2004.

MOREIRA, F.B.; PRADO, I.N.; SOUZA, N.E. et al. Desempenho animal e características da carcaça de novilhos terminados em pastagem de aveia preta, com ou sem suplementação energética. Acta Scienciarum, Animal Sciences, v.27, p.469-473, 2005.

MÜLLER, M.; PRADO, I.N.; LOBO JUNIOR, A.R. et al. Diferentes fontes de gordura sobre o desempenho e características da carcaça de novilhas de corte confinadas. Acta Scientiarum. Animal Sciences, v.27, p.131-137, 2005.

MÜLLER, L. Normas para avaliação de carcaça e concurso de carcaças de novilhos. 2.ed. Santa Maria: Universidade Federal de Santa Maria, 1987. 31p.

NAGARAJA, T.G.; NEWBOLD, C.J.; VAN NEVEL, C.J. et al. Manipulation of ruminal fermentation. In: HOBSON, P.N.; STEWART, C.S. (Eds.). The rumen microbial ecosystem. 2.ed. Great Britain: Blackie Academic \& Professional, 1997. p.524-632.

NATIONAL RESEARCH COUNCIL - NRC. Nutrient requeriments of dairy cattle. 7.rev.ed. Washinton, D.C: Academic Press, 2001. 381p.

NELSON, M.L.; MARKS, D.J.; BUSBOOM, J.R. et al. Effects of supplemental fat on growth performance and quality of beef from steers fed barley-potato product finishing diets: I. Feedlot performance, carcass traits, appearance, water binding, retail storage, and palatability attributes. Journal of Animal Science, v.82, p.3600-3610, 2004.

NICHOLSON, T.; OMER, S.A. The inhibitory effect of intestinal infusions of unsaturated long-chain fatty acids on forestomach motility of sheep. British Journal of Nutrition, v.50, p.141-149, 1983.

OLIVEIRA, E.A.; SAMPAIO, A.A.M.; FERNANDES, A.R.M. et al. Desempenho e características de carcaça de tourinhos Nelore e Canchim terminados em confinamento recebendo dietas com cana-de-açúcar e dois níveis de concentrado. Revista Brasileira de Zootecnia, v.38, p.2465-2472, 2009.

OSÓRIO, J.C.S.; OSÓRIO, M.T.M. Produção de carne ovina: técnicas de avaliação in vivo e na carcaça. Pelotas: Universidade Federal de Pelotas, 2005. 82p.

PALMQUIST, D.L. Influence of source and amount of dietary fat on digestibility in lactating cows. Journal of Dairy Science, v.74, p.1354-1360, 1991.

PEREZ ALBA, L.M.; DE SOUZA CAVALCANTI, S.; PEREZ HERNANDEZ, M. et al. Calcium soaps of olive fatty acids in the diets of manchega dairy ewes: effects on digestibility and production. Journal of Dairy Science, v.80, p.3316-3324, 1997.

PUTRINO, S.M.; LEME, P.R.; SILVA, S.L. et al. Exigências líquidas de proteína e energia para ganho de peso de novilhos Nelore alimentados com dietas contendo grão de milho úmido e gordura protegida. Revista Brasileira de Zootecnia, v.35, p.301-308, 2006.

REIS, J.C.; LÔBO, R.B. Interações genótipo-ambiente nos animais domésticos. Ribeirão Preto: Gráfica e Editora FCA, 1991. 194p.

RESTLE, J.; CERDÓTES, L.; VAZ, F.N. et al. Características de carcaça e da carne de novilhas Charolês e 3/4 Charolês 1/4 Nelore, terminadas em confinamento. Revista Brasileira de Zootecnia, v.30, p.1065-1075, 2001. 
RIBEIRO, T.R.; PEREIRA, J.C.; OLIVEIRA, M.V.M. et al. Características da carcaça de bezerros holandeses para produção de vitelos recebendo dietas com diferentes níveis de concentrado. Revista Brasileira de Zootecnia, v.30, p.2154-2162, 2001.

RLM 2.0 - Ração de lucro máximo. Versão 2.0. LANNA, D.P.D., BARIONI, L.G.; BOIN, C.; TEDESCHI, L.O. (Eds.) Piracicaba: Departamento de Zootecnia, Escola Superior de Agricultura "Luiz de Queiroz", 1999.

SILVA, M.M.C.; RODRIGUES, M.T.; BRANCO, R.H. Suplementação de lipídios em dietas para cabras em lactação: consumo e eficiência de utilização de nutrientes. Revista Brasileira de Zootecnia, v.36, p.257-267, 2007.
VAN SOEST, P.J.; ROBERTSON, J.B. Analysis of forages and fibrous foods: a laboratory manual for animal science. Ithaca: Cornell University, 1985. 202p.

VAZ, F.N.; RESTLE, J. Ganho de peso antes e após os sete meses no desenvolvimento e nas características de carcaça e carne de novilhos charolês abatidos aos dois anos. Revista Brasileira de Zootecnia, v.32, p.699-708, 2003.

VAZ, F.N.; RESTLE, J.; FEIJÓ, G.L.D. et al. Qualidade e composição química da carne de bovinos de corte inteiros ou castrados de diferentes grupos genéticos Charolês x Nelore. Revista Brasileira de Zootecnia, v.30, p.518-525, 2001.

VILJOEN, H.F.; DE KOCKA, H.L.; WEBBB, E.C. Consumer acceptability of dark, firm and dry (DFD) and normal $\mathrm{pH}$ beef steaks. Meat Science, v.61, p.181-185, 2002. 